\title{
SISTEM INFORMASI GEOGRAFIS PENCARIAN LOKASI SPBU BERBASIS ANDROID
}

\author{
Fitri Rizani ${ }^{1)}$ \\ ${ }^{1)}$ Program Studi Informatika, Fakultas Ilmu Komputer, Universitas Almuslim Bireuen \\ e-mail: fitri.asykar@gmail.com
}

\begin{abstract}
[Geographic Information System for Android-Based Searching of Locations of Gas Stations] This geographic information system is one of the application methods designed for the purpose of mapping the location of gas stations in Bireuen Regency with the application of computer technology both hardware and software so that all geographic information of gas stations locations can be useful. This application is made using J-Query, php and MySQL as database facilities. This information system is designed with context diagrams, DFD and ERD. The output of this information system provides information on the location of gas stations in Bireuen Regency. With the geographical system of mapping the location of gas stations, it can provide convenience for motorists in refueling at the nearest gas station. The results of this study found that the system developed has been running as expected. The geographic information system for finding gas station locations can be run on the android platform. In this system, it is also possible to add new gas station data by the admin. For suggestions for future development, it is necessary to add details about each gas station in the system, such as fuel stock info, gas station detail info, additional facility info and operating hours.
\end{abstract}

Keywords: : SPBU; GIS; PHP; Mysql; Jquery.

\begin{abstract}
Abstrak
Sistem informasi geografis ini merupakan salah satu metode aplikasi yang dirancang untuk keperluan untuk memetakan lokasi SPBU di Kabupaten Bireuen dengan penerapan teknologi komputer baik hardware maupun software sehingga seluruh informasi geografis lokasi SPBU dapat bermanfaat. Aplikasi ini dibuat menggunakan fasilitas J-Query, php dan MySQL sebagai basisdata. Sistem infomasi ini dirancang dengan diagram kontek, DFD dan ERD. Output dari sistem informasi ini memberikan informasi lokasi SPBU di Kabupaten Bireuen. Dengan adanyan sistem geografis pemetaan lokasi SPBU dapat memberika kemudahan kepada pengendara dalam pengisian bahan bakar minyak pada SPBU terdekat. Hasil dari penelitian ini didapatkan bahwa sistem yang dikembangkan telah berjalan sesuai dengan yang diharapkan. Sistem informasi geografis pencarian lokasi SPBU dapat dijalankan pada platform android. Pada sistem ini juga dapat dilakukan penambahan data SPBU baru oleh admin. Untuk saran pengembangan di masa yang akan datang, perlu ditambahkan detail mengenai tiap SPBU yang ada dalam sistem, seperti info stok BBM, info detail SPBU, info fasilitas tambahan serta jam operasional.
\end{abstract}

Kata Kunci: SPBU; GIS; PHP; Mysql; Jquery.

\section{Pendahuluan}

Perkembangan teknologi saat ini lebih mengedepankan pada penggunaan perangkat mobile seperti smartphone(ANSHORI, 2017). Pada dasarnya smartphone diciptakan tidak hanya untuk menelpon ataupun mengirim pesan saja, tetapi smartphone dapat melakukan beberapa hal yang sebelumnya hanya bisa dilakukan pada perangkat PC (Personal Computer), seperti mengakses internet, menonton video, mendengarkan musik, dan juga membaca dokumen (Salsabiila, 2019). Saat ini smartphone juga telah dilengkapi dengan fasilitas-fasilitas canggih yang memungkinkan user melakukan apapun yang dia inginkan sesuai dengan kebutuhannya seperti fasilitas kamera berkualitas tinggi dan juga pixel yang besar sehingga 
dapat memungkinkan user untuk mengambil gambar dengan hasil yang maksimal baik untuk foto maupun video, adapun fitur lain seperti GPS (Global Positioning System), Wi-Fi hotspot, dan juga tethering (Gunawan, 2019; Rahmadi, 2019; Wicaksono \& Nurseto, 2018).

Selain itu, saat ini smartphone juga telah dilengkapi dengan OS (Operating System) seperti Android, iOS, dan juga Windows Phone (Wijonarko \& Aji, 2018). Khusus untuk sistem operasi Android yang dikembangkan oleh Google, hampir semua source code untuk aplikasi- aplikasinya dipublikasikan, sehingga setiap orang dapat mengembangkan aplikasi tersebut sesuai dengan keinginan dan juga kebutuhan masingmasing user.

Dewasa ini setiap orang membutuhkan kemudahan didalam melakukan berbagai macam hal, tidak terkecuali kebutuhan akan BBM (Bahan bakar Minyak). Bagi pengguna kendaraan bermotor yang masih menggunakan BBM sebagai bahan bakar utama di dalam berkendara, BBM merupakan elemen penting agar kendaraan tersebut bisa digunakan ataupun dijalankan sebagai mana mestinya. SPBU (Stasiun Pengisian Bahan Bakar Umum) merupakan tempat dimana pengendara bisa membeli BBM dengan berbagai jenis BBM sesuai dengan pilihan ataupun kebutuhan pengendara.

Akan tetapi saat ini belum terdapat sebuah aplikasi yang dapat memudahkan pengendara untuk mencari dan menemukan dimana lokasi SPBU terdekat dari tempat dia berada. Orang akan kesulitan untuk mencari dimana lokasi SPBU terdekat dari tempat dia berada apalagi jika orang itu merupakan turis ataupun wisatawan yang sedang berkunjung dan juga transit di suatu daerah. Oleh karena itu saat ini dibutuhkan suatu aplikasi yang dapat memudahkan pengguna untuk melakukan pencarian lokasi SPBU terdekat dari lokasi dia berada, dan diharapkan aplikasi ini dapat mempermudah pengguna untuk mencari dimana lokasi SPBU terdekat, sehingga tidak ada lagi pengendara yang mogok di jalan karena kehabisan bahan bakar.

Salah satu teknologi terkini yang dapat diaplikasikan adalah Binary Search yang akan dipadukan dengan perangkat mobile seperti smartphone yang menggunakan sistem operasi Android (Sugiri, Hikmayanti, \& Suharso, 2019; Sulistio, Lutfi, \& Ridwan, 2019). Fitur-fitur yang terdapat di dalam Android seperti kamera, internet, GPS, dan juga kompas akan saling terintegrasi dengan teknologi search yang akan digunakan untuk pembuatan aplikasi ini sehingga nantinya aplikasi ini dapat dijalankan dan diimplementasikan dengan baik (Wijaya, Maulana, \& Danil, 2021). merupakan suatu teknologi yang memungkinkan menggabungkan antara dunia nyata dengan dunia maya secara real time. Untuk sampel data penulis mengambil object peneitian berdasarkan data yang penulis gunakan dalam pembuatan sistem yaitu pada SPBU Paya Meuneng, SPBU Cot Gapu, SPBU Bireuen, SPBU Juli

\section{Metode}

Adapun metode yang digunakan dalam penelitian ini adalah sebagai berikut:

1. Observasi

Observasi dilakukan dengan cara melakukan pengamatan dan melakukan perancangan sistem dengan menganalisis kebutuhan pengembangan sistem.

2. Studi Pustaka

Studi pustaka dilakukan dengan mengumpulkan literatur terkait dengan pengembangan sistem informasi geografis lokasi SPBU

Adapun metode pengembangan sistem yang dilakukan adalah dengan metode prototype, dimana pada metode ini dilakukan pengembangan sistem yang berorientasi kepada kebutuhan pengguna. Sistem akan diperbaiki secara terus menerus apabila terdapat bug. Sistem dikembangkan dalam beberapa tahapan, dimana tiap tahapan akan dicapai kondisi finish state dimana tidak lagi terdapat bug dan sudah sesuai dengan kebutuhan pengguna. Setelah tahap tersebut selesai, maka akan dilanjutkan tahapan berikutnya dengan mengulangi langkah yang sama dengan tahap sebelumnya.

\section{Hasil dan Pembahasan}

A. Tampilan Aplikasi

Pada halaman ini terdiri dari beberapa menu yaitu sebagai berikut :

1. Halaman Utama

Halaman ini merupakan halaman utama yang tampil disaat sistem dijalankan, pada halaman ini terdapat beberapa menu yaitu menu home, menu tentang, menu lokasi dan menu admin. 


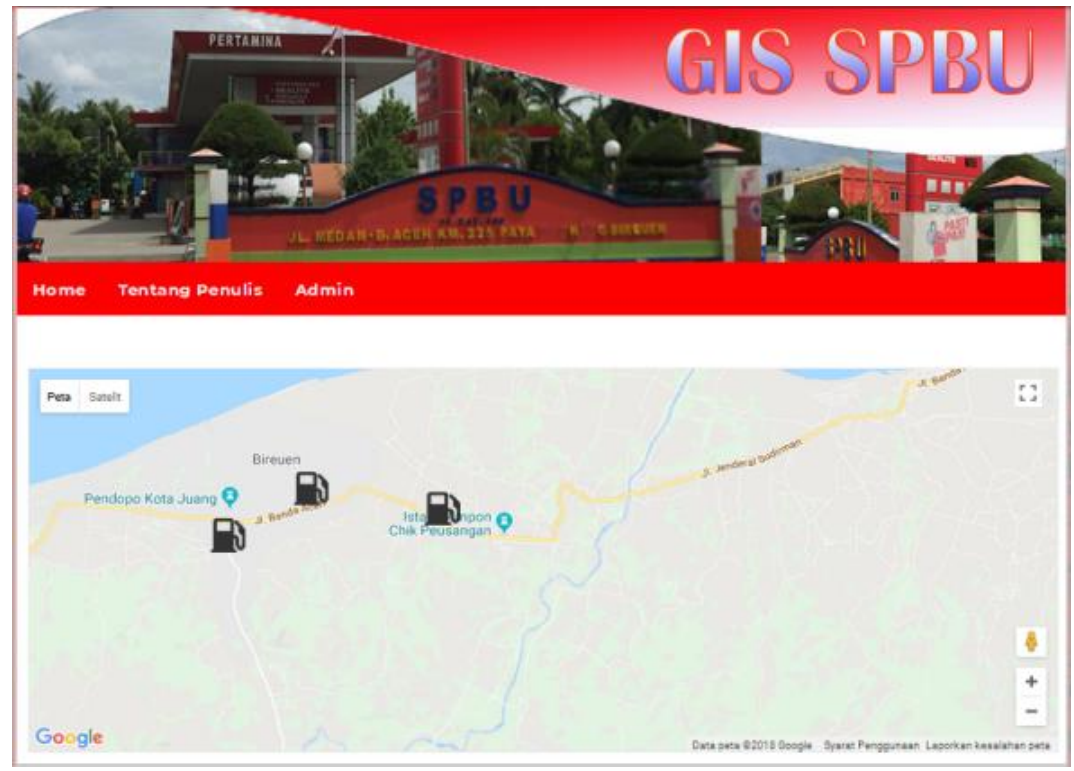

Gambar 1. Halaman Utama

2. Halaman Peta Lokasi SPBU

Halaman ini merupakan halaman yang menampilkan data lokasi SPBU yang ditampilkan dalam google map. Pada icon lokasi memiliki koordinat letak SPBU sehingga pengendara memudahkan dalam menemukan SPBU terdekat. Jarak lokasi SPBU ditampilkan langsung beserta lama tempuh untuk lokasi SPBU tersebut.

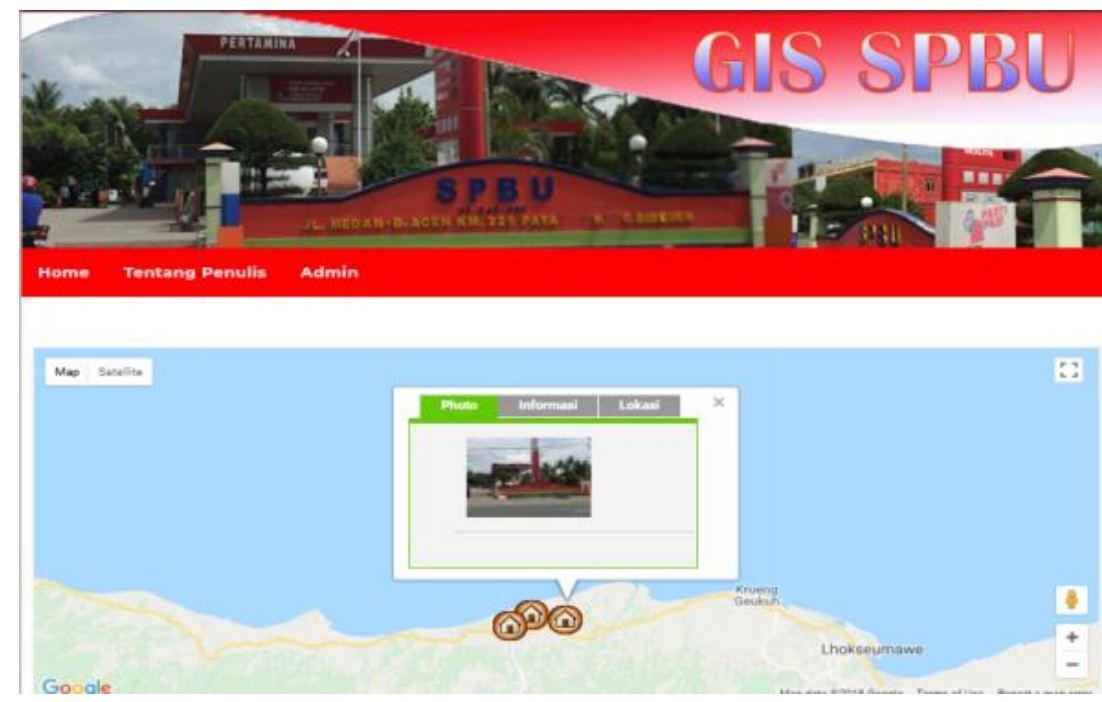

Gambar 2. Halaman Detil Lokasi

3. Halaman Login Administrator

Halaman ini merupakan halaman login administrator untuk masuk ke dalam sistem dengan memasukkan username dan password, jika username dan password yang dimasukkan valid maka admin masuk ke sistem dan jika username dan password yang dimasukkan tidak valid makan admin harus login kembali. Berikut tampilan halaman login administrator 


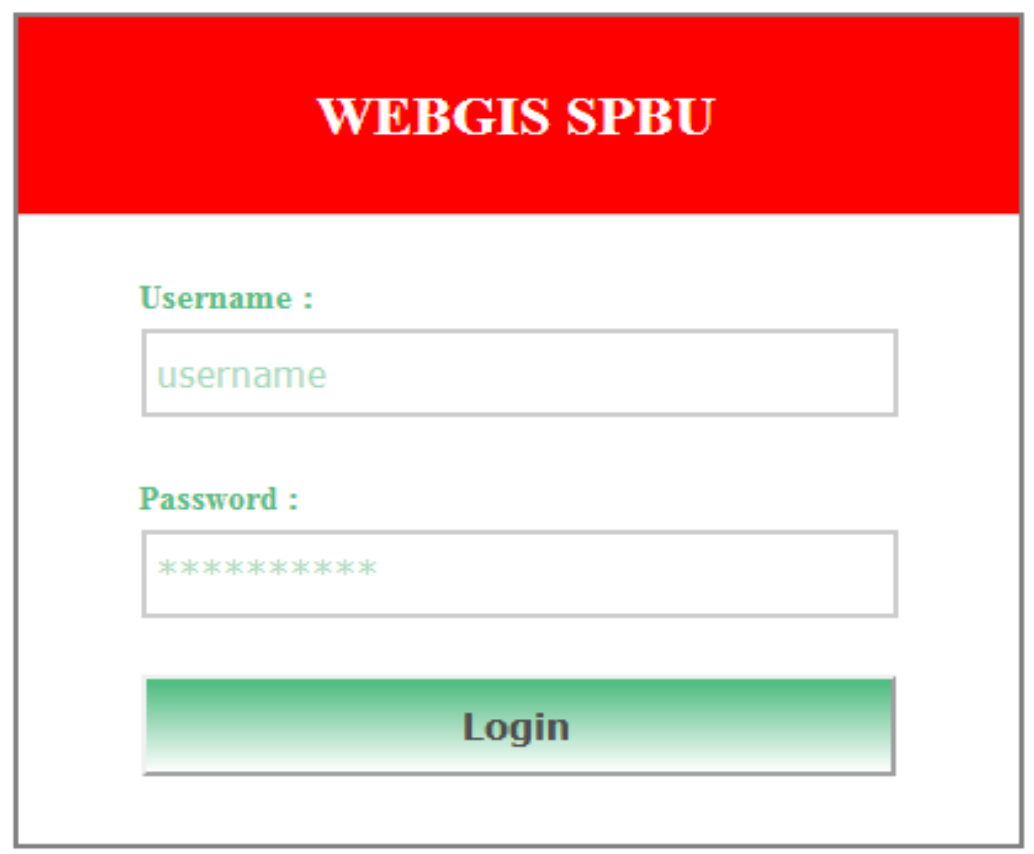

Gambar 3. Halaman Login Sistem

4. Halaman Utama Admin

Halaman ini merupakan halaman index admin. Pada halaman ini ditampilkan selamat datang admin, dan ada beberapa menu antara lain yaitu : menu home, menu edit menu utama, edit manajemen user, menu lokasi, menu kategori lokasi dan menu logout. Berikut tampilan halaman utama admin.

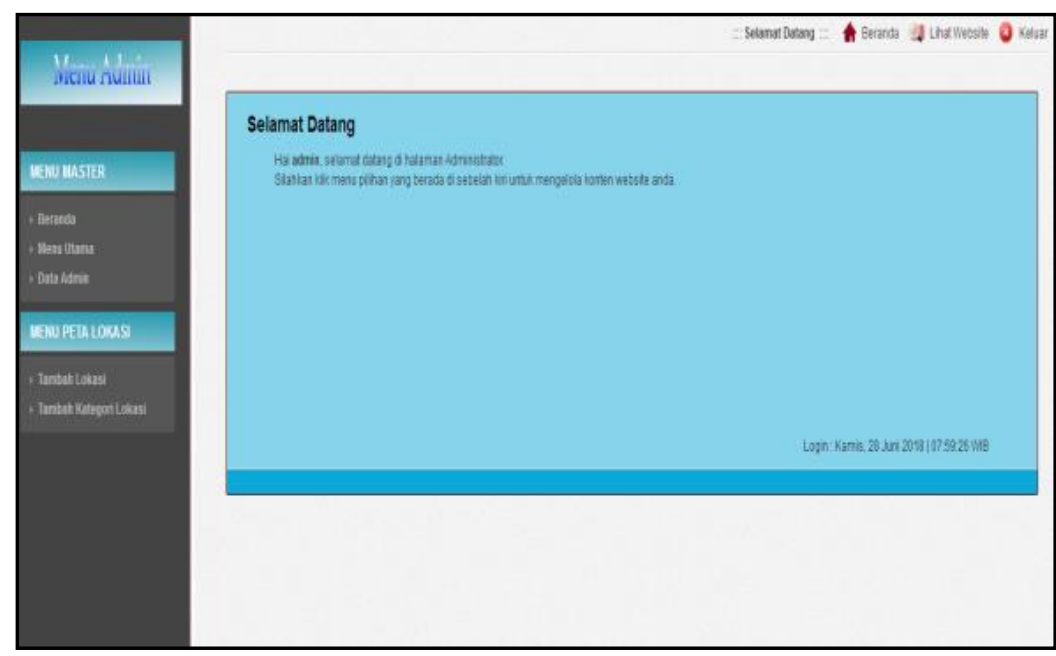

Gambar 4. Halaman Utama Admin

5. Halaman Data Menu Utama

Halaman ini merupakan halaman yang menampilkan menu utama pada sistem, dimana menu dapat ditambah dan edit, hapus oleh admin. Berikut tampilan halaman menu utama admin. 


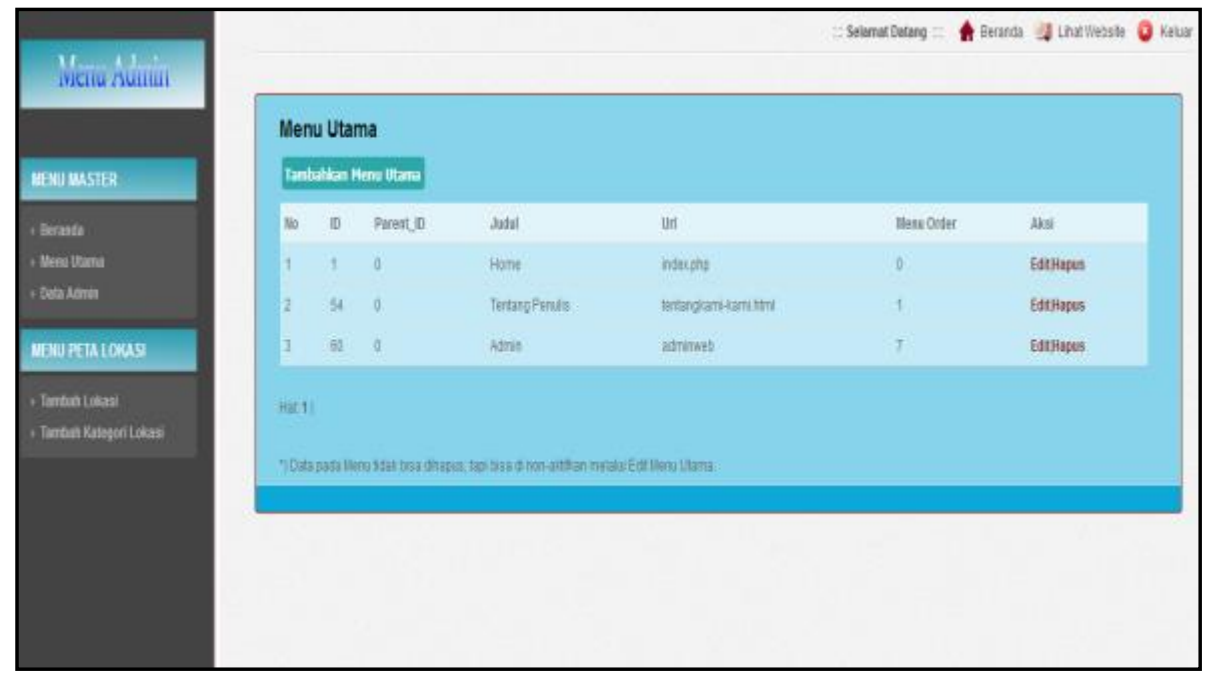

Gambar 5. Halaman Menu Utama

6. Halaman Input Menu Utama

Halaman ini merupakan halaman input menu utama yang di input oleh admin setelah berasil melakukan login. Pada halaman ini tersedia sebuah form input data dengan beberapa fieldyang berfungsi sebagai menu utama sistem informasi geografis. Berikut ini tampilan halaman menu utama.

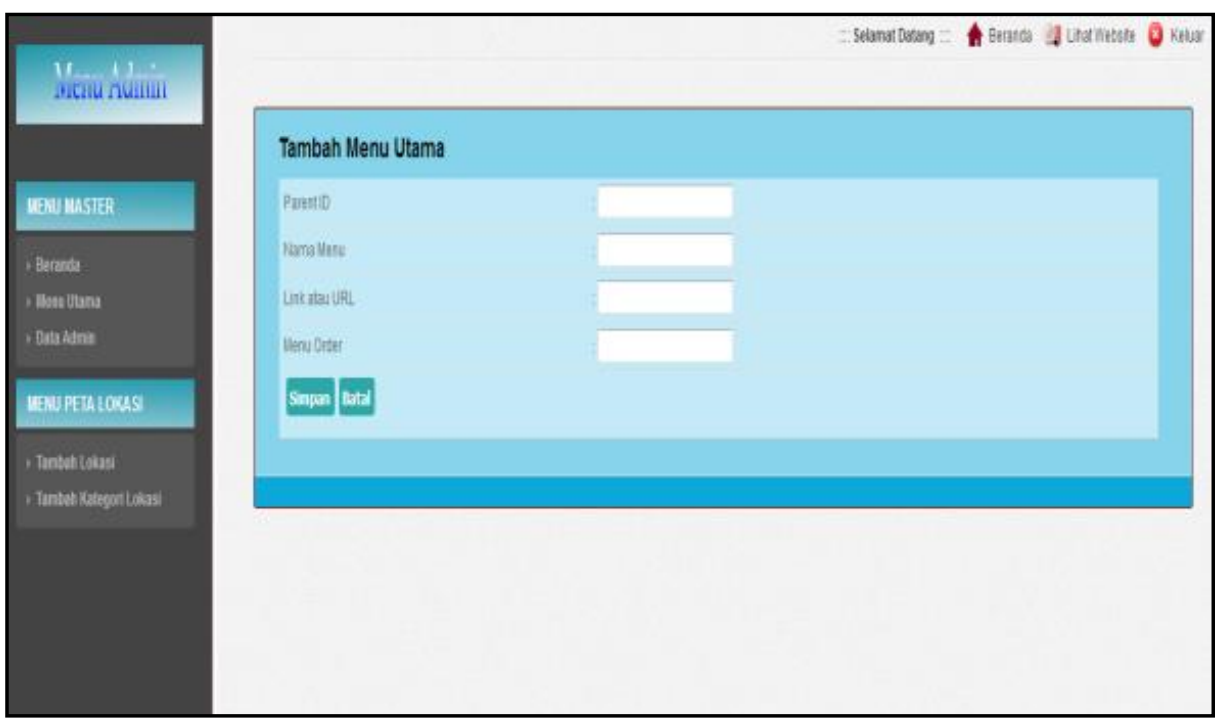

Gambar 6. Halaman Tambah Menu Utama

7. Halaman Input User

Halaman ini merupakan halaman input user yang di input oleh admin setelah berasil melakukan login. Pada halaman ini tersedia sebuah form input data dengan beberapa fieldyang berfungsi sebagai menu utama sistem informasi geografis. Berikut ini tampilan halaman menu utama. 


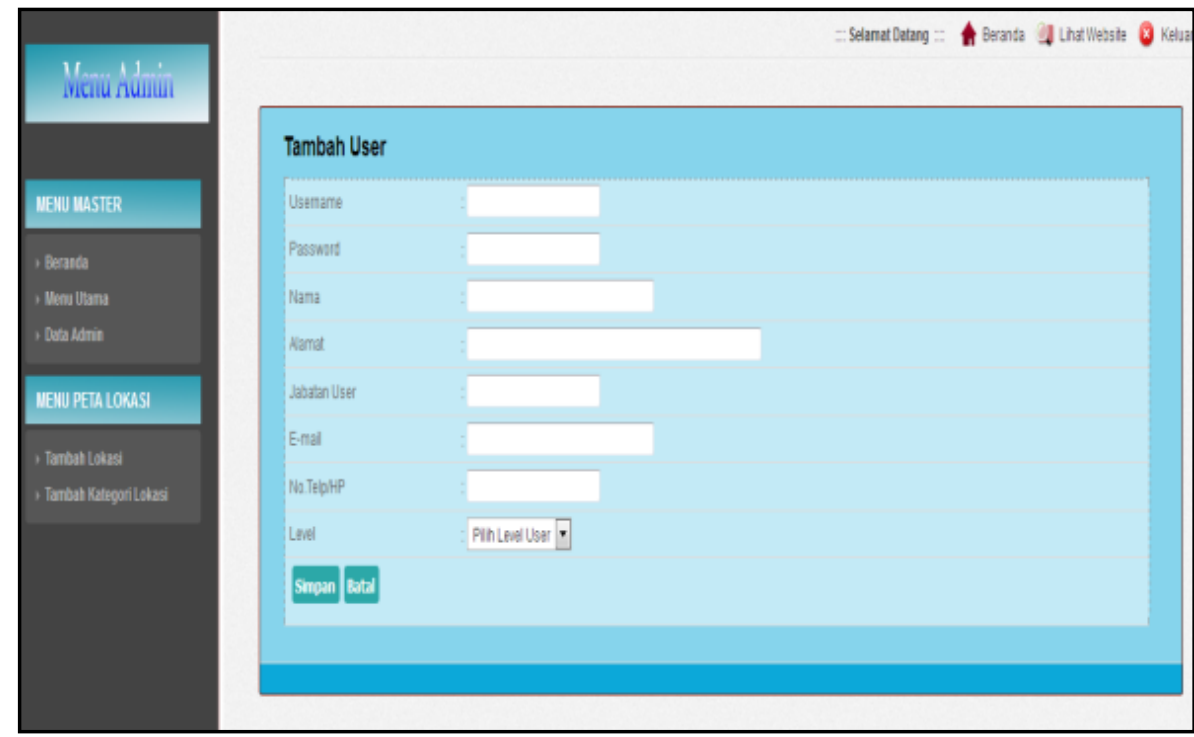

Gambar 7. Halaman Tambah User

8. Halaman Data Lokasi SPBU

Halaman ini merupakan halaman yang menampilkan data lokasi SPBU pada sistem, dimana data lokasi dapat ditambah dan edit, hapus oleh admin. Berikut tampilan halaman lokasi SPBU.

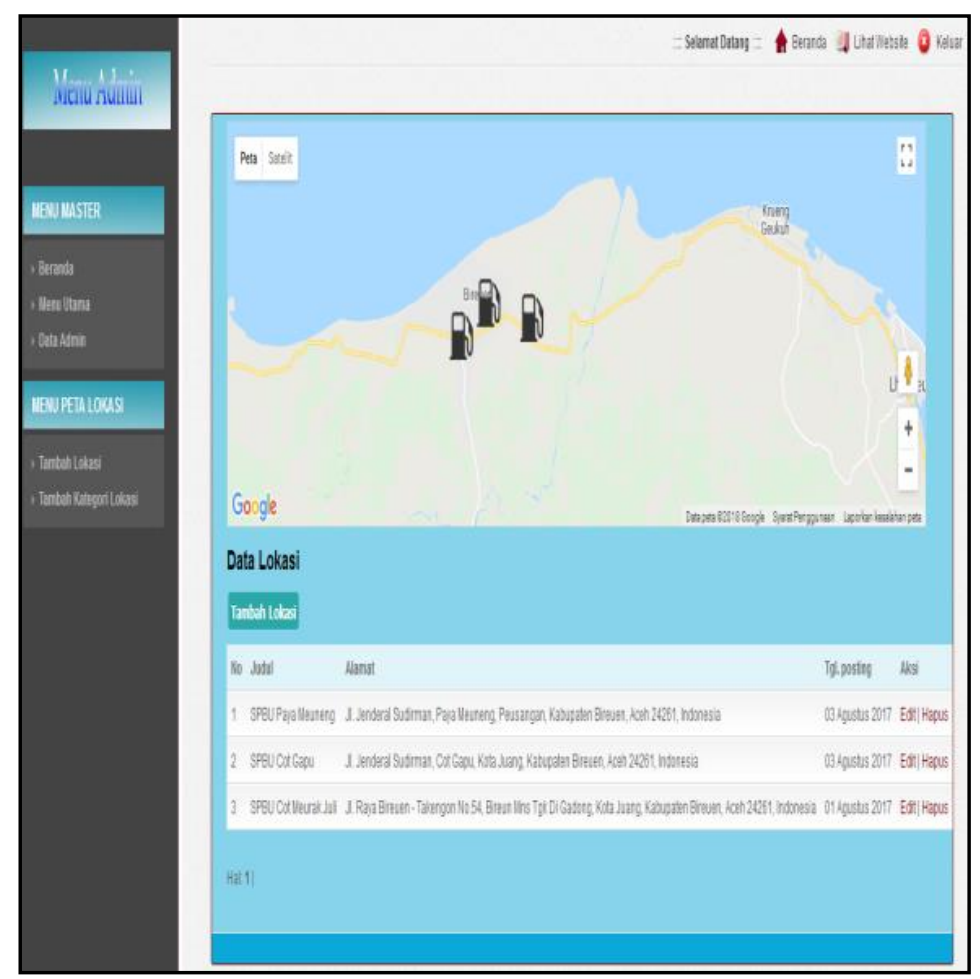

Gambar 8. Halaman Data Lokasi

\section{Kesimpulan}

Kesimpulan yang dapat diambil dari pembangunan Sistem Informasi Geografis Lokasi SPBU Kota Bireuen berbasis Android adalah sebagai berikut :

1. Hasil pengujian menunjukkan aplikasi ini mampu menangani pengolahan data lokasi SPBU sehingga memudahkan pengendara dalam proses pencarian lokasi SPBU terdekat

2. Sistem ini menghasilkan solusi bagi pengendara dalam pengisian bahan bakar minyak sesuai dengan kriteria yang ditentukan. 
3. Sistem sudah memenuhi kebutuhan minimal, ditandai dengan kesesuaian antara analisa kebutuhan dengan fungsionalitas sistem yang dibangun.

4. Sistem dapat diakses melalui android dan web.

\section{Daftar Pustaka}

ANSHORI, M. (2017). Rancang Bangun Aplikasi Rekomendasi Tempat Wisata Menggunakan Metode Logika Fuzzy Berbasis Teknologi Mobile (Kabupaten Banyuwangi). University of Muhammadiyah Malang.

Gunawan, I. (2019). Pembangunan Aplikasi Bike Messenger Dengan Fitur Rekomendasi Rute Alternatif Dan Penentuan Tarif Berdasarkan Elevasi Kalori Pada Smartphone Berbasis Android. Universitas Komputer Indonesia.

Rahmadi, D. D. (2019). Pembangunan Aplikasi Smartphone Berbasis Android Membantu Menjaga Kesehatan Mata Dengan Memanfaatkan Sensor Smartphone. Universitas Komputer Indonesia.

Salsabiila, K. (2019). Fungsi Smartphone Pada Mahasiswa Penyandang Tunanetra Di Kampus B Universitas Airlangga. UNIVERSITAS AIRLANGGA.

Sugiri, D., Hikmayanti, H., \& Suharso, A. (2019). RANCANG BANGUN APLIKASI KAMUS SUNDAINDONESIA DENGAN METODE BINARY SEARCH BERBASIS ANDROID. Techno Xplore: Jurnal Ilmu Komputer dan Teknologi Informasi, 4(1), 1-14.

Sulistio, B., Lutfi, S., \& Ridwan, R. (2019). APLIKASI KAMUS BAHASA TALIABU BERBASIS ANDROID DENGAN MENGGUNAKAN METODE BINARY SEARCH. JIKO (Jurnal Informatika dan Komputer), 2(2), 67-72.

Wicaksono, A. C., \& Nurseto, S. (2018). Pengaruh Kualitas Produk, Fitur Produk dan Harga terhadap Niat Beli Ulang Melalui Kepuasan Konsumen sebagai Variabel Intervening (Studi pada Konsumen Smartphone Xiaomi di Kota Semarang). Jurnal Ilmu Administrasi Bisnis, 8(1), 34-42.

Wijaya, A., Maulana, M. F., \& Danil, M. (2021). APLIKASI PENCARIAN RESEP MASAKAN KHAS BENGKULU MENGGUNAKAN ALGORITMA BINARY SEARCH BERBASIS ANDROID. Jurnal Media Infotama, 17(1).

Wijonarko, D., \& Aji, R. F. (2018). Perbandingan Phonegap dan React Native Sebagai Framework Pengembangan Aplikasi Mobile. Jurnal Manajemen Informatika dan Sistem Informasi, 1(2), 1-7. 